\title{
Contesting the (Super)Natural Origins of Ebola in Macenta, Guinea: Biomedical and Popular Approaches
}

\author{
Séverine Thys
}

On 25 March 2014, a declaration from the World Health Organisation (WHO) and the Center for Disease Control (CDC) officially announced that Ebola-Zaire haemorrhagic fever affected four districts in south-eastern Guinea, Guéckédou, Macenta, Nzérékore and Kissidougou, and suspected cases were reported in Liberia and Sierra Leone. That day, there were already - in Guinea alone-a total of 86 suspected cases and 60 deaths. ${ }^{1}$ Among the multiple measures and interventions that would follow, a retrospective epidemiological study of the cases and deaths that occurred during the silent phase of the epidemic - the first phase without identification of all fatal cases-was launched to document the chain of transmission. ${ }^{2}$ The latter would postulate that the Ebola virus appeared in south-eastern Guinea

\footnotetext{
S. Thys $(\varangle)$

Department of Virology, Parasitology, and Immunology, Faculty of Veterinary Medicine, Ghent University, Ghent, Belgium

Department of Veterinary Public Health and Food Safety, Faculty of Veterinary Medicine, Ghent University, Ghent, Belgium

(C) The Author(s) 2019

C. Lynteris (ed.), Framing Animals as Epidemic Villains, Medicine and Biomedical Sciences in Modern History, https://doi.org/10.1007/978-3-030-26795-7_7
} 
at the end of December 2013 with the death of a two-year-old child in the village of Méliandou in Guéckédou Prefecture, four days after the onset of symptoms (fever, black stools and vomiting). ${ }^{3}$ This patient would be considered from now on as the 'case zero', the index case stemming the severe Ebola virus disease (EVD) epidemic of West Africa from apparently a single zoonotic transmission event. ${ }^{4}$ But then, with the idea of the spillover taking central stage the question arises: Which animal species, the mythic 'animal zero', came to bear the burden of epidemic blame this time? ${ }^{5}$

While this retrospective epidemiological study was perceived as essential for limiting high-risk exposures and for quickly implementing the most appropriate control interventions, these investigations (biomedical experts deployed from the rich North) were tempted to mimic and fulfil the 'outbreak narrative' imposed by the global health governance. ${ }^{6}$ In this endeavour, rather than discovering the epidemiological origin, what becomes crucial is to quickly identify the carriers-'these vehicles necessary to drive forward the plot', which often function as the outbreak narrative's scapegoats. ${ }^{7}$ Historically always located at the boundary of the human social body, the ideal candidate to carry this role in the EVD epidemic of 2014-2016 was once again the wild and villainous non-human animal. Because the pathways for emergence are in any way 'natural' or 'sylvatic', according to the dominant Western biomedical model, the inclusion of wildlife in the epidemiology and the evolution of emerging infectious diseases is justified, yet its role is often misrepresented. ${ }^{8}$ Although the probability of a humans contracting the disease from an infected animal still remains very low, certain cultural practices sometimes linked with poverty, especially 'bushmeat' hunting, continue to be seen as the main source of transgression of species boundaries. ${ }^{9}$ In the African context, research into emerging infections from animal sources implicates nonhuman primate 'bushmeat' hunting as the primary catalyst of new diseases. ${ }^{10}$ Since the virus of Ebola was identified for the first time in Zaïre in 1976 and qualified as the first 'emerging' virus according to the new world clinic called 'global health', the link between animal and human health appears based on an 'us vs. them'. ${ }^{11}$

After the formal confirmation of the aetiological agent in March 2014, the epidemic quickly took on an unprecedented scale and severity in several respects. It was declared by the WHO as an 'extraordinary event' because of its duration, the number of people infected, and its geographical extent which made it the largest Ebola epidemic recorded in history until then. ${ }^{12}$ To these quantifiable impact measures were added sociological, ecological, 
political and economic phenomena that are much more complex to decrypt. These have had a profound impact on society, well beyond the remote rural environment that was typically affected by preceding epidemics. ${ }^{13}$ By threatening major urban areas, these 'geographies of blame' or 'hotspots' (usually at the margin of modern civilisation and configuring specific areas of the world or the environment into the breeding grounds of viral ontogenesis) have been mapped by 'virus-hunters' to update 'predictions about where in Africa wild animals may harbour the virus and where the transmission of the virus from these animals to humans is possible'. ${ }^{14}$ In addition to this epidemic's extraordinary character, by spreading beyond the capacities of humanitarian aid, this new biomedically unsolved complexity conferred upon it a status of 'exceptionality' also by 'proclaiming the danger of putting the past in (geographical) proximity with the present'. ${ }^{15}$ This status had the effect, among others, of the most intense involvement, perhaps more visibly than before, of different disciplines, from human and animal health to the social sciences, in the international response. Anthropology's response in particular was 'one of the most rapid and expansive anthropological interventions to a global health emergency in the discipline's history'. ${ }^{16}$ Yet it is very critical that the collective social science experiences acquired during this West African Ebola epidemic remained engaged to addressing future outbreaks and beyond. They translated and shared anthropological knowledge between scholars by including translation for public health specialists, transmitting that knowledge to junior scientists, and engaging in ongoing work to develop relevant methodology and theory. ${ }^{17}$

Among the three West African countries most affected by the epidemic, Guinea-Conakry has been more marked by this dual 'exceptionality', that is to say, both epidemiological and social. Beside the exceptionalism described by the Senegalese anthropologist Faye on the strong and sometimes violent demonstrations of popular reticence with regard to the activities of the 'Riposte', Guinea was also marked by a higher case fatality rate, as shown in the WHO report of 30 March 2016. Globally raised up to more than 66\% (while knowing that the number of cases and deaths was probably underreported), this case fatality rate confirmed the seriousness of the disease in a Guinean context where the Ebola virus had never hit before. ${ }^{18}$ Neither the medical community, nor the population, nor the authorities had so far experienced it.

Despite all the measures implemented, to the question, why did we observe a higher case fatality rate in Guinea compared to that of other 
countries, a multitude of factors can be advanced. The latter deserve to be the subject of multidimensional analyses, especially as this global lethality has manifested itself differently according to the geographical region of the country. The highest fatality rate was observed in forest Guinea $(72.5 \%$, $1230 / 1697)$, the region of origin of the index case and main epicentre of the epidemic. Was this due to exclusively biomedical factors, such as a lower level of immunity among the Guinean population? ${ }^{19}$ Or was it because of late care that would have given patients less chance of surviving and fighting the virus? But then, why did people infected with the virus later arrive at Ebola treatment centres (ETC) in Guinea? Was it due to a poorer and more limited health system and frailer medical and health infrastructure than Liberia and Sierra Leone at the time of the epidemic? Or was it due to less effective coordination work by international and national teams in responding to the epidemic? ${ }^{20}$ Or simply because in Guinea the local communities were much more reluctant and intentionally opposed to the deployment of humanitarian and health assistance? Although sharing broadly similar cultural worlds, what can therefore explain this notable difference of social resistance between the affected countries?

Combined with a divergent political practice and lived experiences of the state, especially between Sierra Leone and Guinea, the working hypothesis drawn from my ethnographic observations in Macenta and related literature review is that part of the continuing episodes of hostility and social resistance manifested by Guinean communities regarding the adoption of the proposed control measures against the scourge of Ebola has its origins in the divergence between explanatory systems of the disease; on the one hand, biomedical explanatory systems, and, on the other hand, popular explanatory systems. ${ }^{21}$ In March 2014, when Ebola hemorrhagic fever was formally identified a few months after the first death, epidemiologists and local populations each actively began to trace and understand this first human-to-human transmission chain of the disease, as well as its triggering event. Evolving most often in parallel, and overlapping at times, these epidemiological and popular investigations generally refer to different explanatory models, some more biomedical ('natural') and others more mysticoreligious ('supernatural'). The purpose of this chapter is to trace and reflect on the interpretations of the origin and transmission of the Ebola disease, as perceived and explained by the population, and to contrast them with the explanatory model of epidemiologists. 


\section{Carriers ANd Their Transgressions}

In order to interrupt the two routes of EVD transmission, namely from animal reservoirs to humans and between human infection, humanitarian responses followed the following public health logic: 'bushmeat' hunting, butchering and consumption should be banned and the ill should be isolated within ETCs and burials should be made safe. Yet, the interventions related to this reasoning had unattended consequences and, together with the Ebola disease itself, they 'disrupted several intersecting but precarious social accommodations that had hitherto enabled radically different and massively unequal worlds to coexist'. ${ }^{22}$

Carriers, in the case of human-to-human transmission, are generally perceived as the ones promulgating the epidemics and are marked with transgressive attributes intrinsic to their 'contagiousness' (e.g. wanton or deviant sexuality for the HIV epidemic, uncleanliness for the cholera epidemic, immigration for typhoid). ${ }^{23}$ However, in zoonosis-related diagnostic discourses, pathogens have the potential to reverse relations between humans and animals in such a way that the carrier becomes the victim. ${ }^{24}$ Located at the 'interface' between humans, animals and the (natural) environmentalready proved to be a virtual place where deadly pandemic risks lie waiting for humanity-'forest people' from Guinea were rendered both carriers of the disease and victims of the villainous role of nonhuman animals. ${ }^{25}$ The response to the fear of pandemics has been made unmistakable: we have to shield off humanity from nature. This mindset strongly adheres to the prevailing 'culture-nature divide' which is also depicted through zoonotic cycles diagrams further operating both as pilots of human mastery over human-animal relations and as crucial sites of unsettlement for the latter. ${ }^{26}$ Wild animals became public enemy number one, together with those who were supposedly facilitating the transgression of the boundaries between the cultural and natural world with (or because of) their culturally 'primitive' or 'underdeveloped' practices. By framing 'bushmeat' hunting, as well as local burials, as the main persisting cultural practices among the 'forest people' to explain (or to justify) the maintenance of the EVD transmission during the West African epidemic, the notion of culture that fuelled sensational news coverage has strongly stigmatised this 'patient zero' community both globally and within Guinea, and has been employed to obscure the actual, political, economic and political-economic drivers of infectious disease patterns. ${ }^{27}$ 


\section{MACenta, THe EPICENTRE}

Appointed by my former institute, the Institute of Tropical Medicine of Antwerp, Belgium (ITM), to the WHO, I was sent to Guinea-Conakry from the end of October to the end of November 2014 for a four-week mission by the Global Outbreak Alert and Response Network (GOARN). ${ }^{28}$ Since August 2014, the country had been in the largest and longest phase of the epidemic, the second recrudescence which would also be the most intense one up until January 2015. ${ }^{29}$ I first spent a week in Conakry to follow the implementation of a social mobilisation project (project of monitoring committees at the level of each commune in the urban area). Then, following an evaluation of the situation qualified as catastrophic by the national coordinator of the WHO, it was in Macenta, Forest Guinea, where I was deployed. Macenta, located east of Guéckédou, was the prefecture considered to be the epicentre of this new outbreak of Ebola and where transmission was the most intense. This district would remain one of Guinea's most affected regions. By October 2014, Macenta, where catastrophic scenarios seemed possible, had already a cumulative number of almost 600 cases since the beginning of the epidemic. The epidemiological situation was out of control, with a lack of material, human and financial resources. On arrival, there was still only one Transit Center (CDT). A new ETC was being finalised by MSF Belgium. Its management would be taken over a few weeks later by the French Red Cross. Due to the long rainy season, the road used for bringing confirmed cases from Macenta to the Guéckédou treatment centre was in a deplorable state, slowing down the start of treatment and increasing the risk of transmission during transportation.

It is as a medical anthropologist that I have been involved in Guinea's national coordination platform for the fight against Ebola and this within the Commission of 'Social mobilization and communities engagement', also named locally the 'communication' unit, in order to document, better understand and help to address the reluctance manifested by the local community. Without going into the debate about the instrumentalisation of anthropologists as simple 'cultural mediators' at the service of humanitarians, I will simply recall here the specific objectives assigned for the mission. ${ }^{30}$ They consisted, on the one hand, in an analysis of rumours and crisis situations in order to propose responsive actions and, on the other hand, in adapting the responses and protocols of the various national and 
international institutions to local conditions, giving priority to comprehensive and participatory approaches.

By integrating the 'communication' unit, I tried to support and animate the meticulous and sensitive work of a whole team working to rebuild trust with communities and to 'open' villages reluctant to receive care interventions. Under the authority of UNICEF Guinea, this communication team also hosted many local associations previously working for the prevention of infectious diseases, such as HIV/AIDS, in the region. The latter had already been mobilised to serve as a relay and to mitigate the unpredictable consequences of the epidemic not foreseen by the Riposte, such as, among other things, sensitisation and reception of healed people and orphans of Ebola, food distribution, and support for people and villages stigmatised by the disease for whom access to the market-purchase and sale of products - was forbidden. Religious representatives of Protestant and Muslim communities also voluntarily joined this platform to learn and then preach preventive behaviour, to comfort the population, as well as to deconstruct and addressed rumours. Their main message was to convince the public that Ebola did indeed exist and 'was a real disease'. Subsequently, the communication unit was finally able to associate the Prefectural Direction of Traditional Medicine of Macenta counting 6122 traditional healers and distributed in the 14 subprefectures of Macenta. The main objective of this new activity was to engage all traditional healers in the fight against EVD by raising the awareness of their patients and their entourage thanks to their high level of credibility in their respective communities. They also undertook to refer their patients directly to the TC if they came to present even one of the symptoms of EVD (fever, diarrhoea [with blood], vomiting [with blood], loss of appetite). A 'health promotion' team managed and financed by MSF Belgium also acted on the ground. Each morning, the different commissions and stakeholders of the Riposte present in Macenta were meeting at the Prefectural Health Directorate (DPS) to discuss and coordinate their activities in the field. ${ }^{31}$ Alongside a Guinean sociologist, consultant for the WHO and the assistant coordinator of the Mission Philafricaine, I was quickly immersed in the realities of the field and in the local strategies elaborated with respect of traditional hierarchies, despite the emergencies. ${ }^{32}$ Their goal was to restore dialogue with the various village representatives who, since the officialisation of the epidemic, had decided to resist Ebola interventions. This was, for instance, the case of the village of Dandano, where deaths had risen to 63; a village whose access was authorised the day after my arrival in Macenta. Although tragic, this 
coincidence made me earn some legitimacy from the other national and international 'fighters'.

It is in this intense and difficult context that the ethnographic observations and their preliminary analysis, presented in this chapter, were collected. The methods employed are based on participant observation, including many informal discussions during meetings with villagers (representatives of youth/notables/sages/women), with religious representatives (Protestant pastors, and imams), with drivers and partners of the coordination community (e.g. Doctors without Borders, Guinean Red Cross, UNICEF among others). Some formal interviews were also conducted with key informants such as healed individuals (Ebola survivors), traditional healers, pastoralists and local actors in the fight.

Biomedical scientific literature and reports on epidemiological data, as well as observational notes, photographs and audio recordings collected in the field, allowed me to trace the interpretations of the origin and transmission of Ebola in a dual perspective: that of epidemiologists, on the one hand, and that of the population on the other. It is through the concept of explanatory models or 'cultural models of the disease' developed by Arthur Kleinman that I attempted to interpret the observations (Fig. 7.1). ${ }^{33}$ This is a conceptual framework that has already been used by Barry and Bonnie Hewlett, Alain Epelboin and Pierre Formenty in their respective interventions during the previous outbreak of Ebola haemorrhagic fever in the Congo in 2003. ${ }^{34}$ To be able to adapt the response and interrupt transmission, it is essential to know and understand how the population perceives the introduction of a disease, especially when it is such a deadly one.

Explanatory or cultural models refer to the explanations of an individual or a culture and to predictions about a particular disease. ${ }^{35}$ These are social and cultural systems that construct the clinical reality of the disease. Culture is not the only factor that shapes their forms: political, economic, social, historical and environmental factors also play an important role in disease knowledge construction. In Kleinmann's model, care systems are composed of three sectors (popular, professional, and traditional) that overlap. In each healthcare system, the disease is perceived, named and interpreted, and a specific type of care is applied. The sick subject encounters different discourses about the illness as she or he moves from one sector to another. Kleinman defines the existence, in each sector, of explanatory models of the disease for the sick individual, for his/her family and for the practitioner, whether professional or not. In general, only one part of an explanatory model is conscious, the other is not. Although the explanatory models seek 


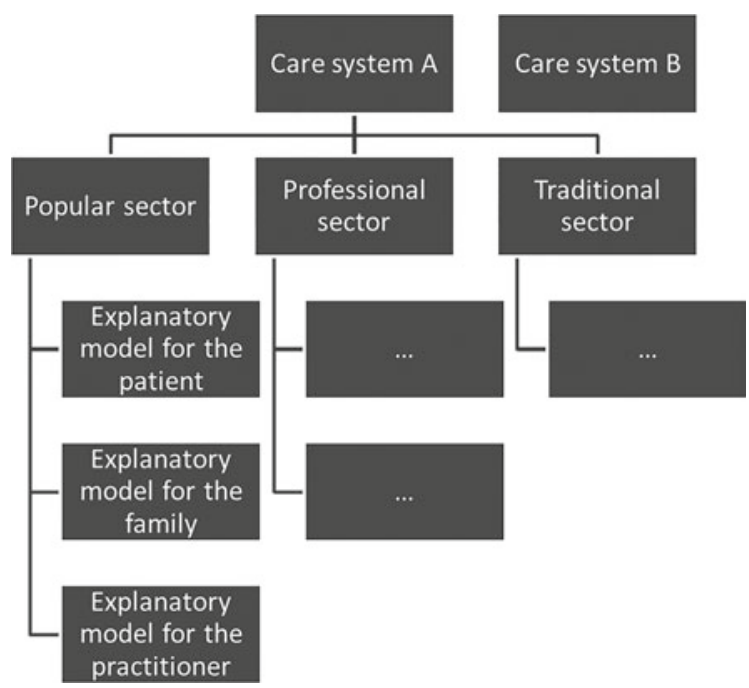

Fig. 7.1 Author's diagram illustrating A. Kleinman's concept of explanatory model of illness

to explain the disease along five main axes, other criteria and characteristics of the disease can, of course, be compared and adapted to the sociocultural and environmental context (the name of the disease, the group at risk, prevention, etc.) as illustrated in the table of 'diagnostic procedures' developed by Hewlett et al. regarding EVD. ${ }^{36}$ From the health district Mbomo in Congo in 2003, they identified five different cultural models including a sorcery model (sorcerer sending spiritual objects into victims), a religious sect (La Rose Croix, a Christian sect devoted to study of mystical aspects of life), an illness model (fever, vomiting, diarrhoea with blood), an epidemic model (illness that comes rapidly with the air/wind and effects many people) and a biomedical model (Ebola Haemorrhagic Fever). ${ }^{37}$ Interestingly, none of the integrated non-biomedical models identified a specific non-human animal as potential source and/or carrier of EVD or hunting and butchering as specific health risk activities for such illness. This further supports the epistemic dissonance observed during many epidemics (including the West African EVD epidemic in this case), between the public health framing of wild meat as hazardous and the practical and social significance of the activities that occasion contact with that hazard. ${ }^{38}$ 


\section{Origin and Chain of Transmission According TO A Biomedical MOdel}

In the case of EVD, it is the biomedical cultural model that prevails among Western health workers. When the alert was launched by the local health authorities on 10 March 2014, two and a half months after the beginning of the disease of the index case, it was virologic investigations that were conducted at first, following the many deaths that occurred during this socalled silent phase. When the Zairre Ebolavirus was identified as the causative agent, retrospective epidemiological investigations of the cases took place, which are crucial during the outbreak of an infectious disease responsible for such high mortality rate.

The first chains of transmission of EVD are presented in the below graph adapted from Baize et al. (2014) (Fig. 7.2). ${ }^{39}$ These investigations are mainly based on the identification of patients and the analysis of hospital documents and reports (results of blood tests carried out in the laboratory), as well as on testimonies and interviews with the affected families, the inhabitants of the villages where the cases occurred, suspected patients and their contacts, funeral participants, public health authorities and hospital staff members. Virologic analyses suggest a single introduction of the virus into the human population. ${ }^{40}$ But the exact origin of the infection of this two-year-old child has not yet been definitively identified, even though the role of bats as natural hosts of the Ebola virus, including this time also the insectivorous species, remains one of the most probable scientific hypotheses. ${ }^{41}$

Up to now, the precise nature of the initial zoonotic event in Guinea remains undetermined and the natural reservoir of the Ebola virus more generally is not yet certain, beside for three species of fruit bat and other insectivorous African bat species known to carry Ebola antibodies and RNA. ${ }^{42}$ Therefore, this informational gap was from the start filled with assumptions during the West African outbreak. Among these assumptions, the elusive link between bats, wild animals and humans triggered high concerns over handling, butchering and consuming wild animals, commonly referred to as 'bushmeat'. ${ }^{43}$ Consequently, these concerns were integrated into public health messages on disease prevention and were translated into a 'bushmeat ban' by governments across the region and enforced during the entire outbreak. ${ }^{44}$ This raises the question of the value of focusing on zoonotic transmission, in particular by fruit bats and non-human primates, which was quickly 

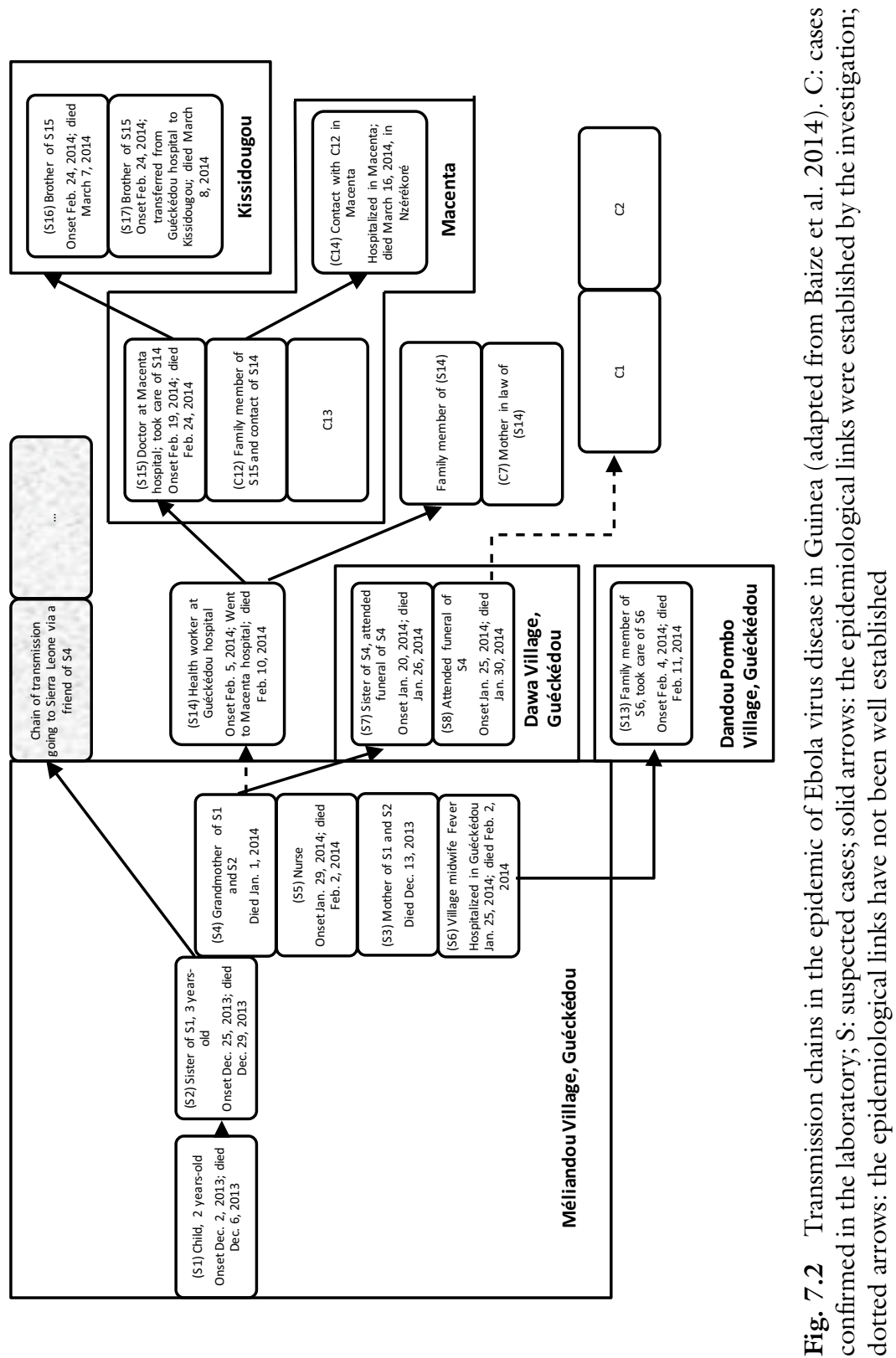
deemed to be of minimal risk, when the biggest threat of infection was from other humans. ${ }^{45}$ Furthermore, it raises the question of whether there is evidence to indicate and confirm that 'bushmeat'-related information included in public health campaigns in the region actually reduced Ebola transmission.

First, hunting and consuming 'bushmeat' for food have long been a part of human history occurring worldwide, serving as an important source of protein, and household income, especially where the ability to raise domestic animals is limited. ${ }^{46}$ The term itself encompasses an extensive list of taxa that are harvested in the wild (ranging from cane rats to elephants and including duiker, squirrels, porcupine, monkeys, non-human primates, bats and hogs) for food, medicine, trophies and other traditional, cultural uses. ${ }^{47}$ Yet, designating the consumption of wild animal meat through the use of the term 'bushmeat' for West Africans instead of 'game', as is the case for Europeans and Americans, by the media, scientific literature and public health campaigns that prohibit this practice, participates in 'semiotics of denigration' and has the effect of perpetuating 'exotic' and 'primitive' stereotypes of Africa. ${ }^{48}$ Although involuntary, the immediate and visceral effect produced in Western minds by the thought of someone eating a chimpanzee, a dog or a bat, for instance, creates a feeling of disgust which downgrades this person, his/her needs and his/her claims on us. ${ }^{49}$ This issue has led to calls to replace the term with 'wild meat' or 'meat from wild animals' ${ }^{50}$ Secondly, while the term 'bushmeat' typically refers to the practice in the forests of Africa, the trade of 'bushmeat', which has expanded over the past two decades, is considered as an example of an anthropogenic factor that provides opportunities for the transmission of diseases from wildlife to humans. ${ }^{51}$ The unsolved reconciliation between present policies and practices and the different values at stake (ecological, nutritional, economic and intrinsic values of wildlife hunted for food) in the actual 'bushmeat crisis', have accentuated the national and global conservation, development and health (infectious disease transmission related) concerns over hunting, eating and trading wild meat. ${ }^{52}$ Thirdly, because of the many competing interests and realities involved, the proscription of hunting and consuming certain species of wild animals - in particular fruit bats and nonhuman primates during the West Africa Ebolavirus outbreak-has resulted in several unintended consequences, has incurred great cost and has had only a limited effect. ${ }^{53}$

In addition to being vague, inconsistent with scientific research and targeted to the wrong audience, messaging that unilaterally stressed the 
health risk posed by wild meat and fomite consumption contradicted the experiences of target publics, who consume wild meat without incident. ${ }^{54}$ Consequently, in addition to having a negative impact on the livelihoods of people living at the frontlines of animal contact, the ban ran the risk of eroding public confidence in the response efforts and fuelling rumours as to the cause of EVD (e.g. that the government was attempting to weaken villages in areas supporting the opposition party, as wild meat is considered an important source of physical 'strength' and energy). ${ }^{55}$ By focusing exclusively on the risk of spillover, we are distorting and concealing aspects of the dynamics at play. What if species boundaries are not perceived in the same way by everyone? What if the transgression of this 'invisible enemy' is spotted at a different intersection, beyond the nature/society binary?

The first chains of human-to-human transmission led to the conclusion that the main vector of contamination was a health professional (S14) who spread the Ebola virus in Macenta, Nzérékoré and Kissidougou in February 2014. The fifteenth patient, a doctor (S15), would have also contaminated his relatives in the same areas. The aetiological agent of this deadly disease (the Ebola virus for some, the transgression of a taboo for others) remained hidden until then and finally became apparent because of clusters of cases in the hospitals of Guéckédou and Macenta. Indeed, even though the high risk of exposures was elucidated, the problem remained hidden for a number of months, mainly because no doctor or health official had previously witnessed a case of Ebola and because its clinical presentation was similar to many other endemic diseases experienced in Guinea, such as cholera, which affects the region regularly. But these signals could also have been blurred by another narrative of the causative agent of these same symptoms. This is very similar to what Genese Marie Sodikoff has identified during the recent bubonic plague epidemic in Madagascar, when scientists elicited survivors' memories of dead rats in the vicinity to reconstruct the transmission chain. Not only were these clues imperceptible to most, but residents had also constructed an alternative outbreak narrative based on different evidence. ${ }^{56}$

Indeed, the mystico-religious beliefs deeply rooted in this region, even within the medical profession, have offered a different interpretation of causality according to a cultural model other than the biomedical model used by epidemiologists. Following James Fairhead, it is important to note that 'cultural' model does not tend here to slip into more totalising ideas of 'culture', such as a model being a 'Kissi culture' (see below) nor its strict 
symmetrical opposite (e.g. a model of the 'humanitarian culture' or of a 'Western culture'). ${ }^{57}$

\section{Origin and Transmission Chain According TO AN 'ANIMIST' MODEL}

At the beginning of the epidemic, for some, the first deaths in Forest Guinea were due to the transmission of the filovirus through contact with animals' and/or patients' body fluids; while for others, these deaths originated from the transgression of a taboo related to the touch of a fetish belonging to a sick person, a member of a secret society belonging to one of the ethnic groups of the region. As a result, susceptibility to Ebola was initially perceived to be restricted to this particular ethnic group, labelling Ebola as an 'ethnic disease' ${ }^{58}$ I decided to name this explanatory model of EVD in Forest Guinea, the 'animist' model, not to further racialise this epidemic, but because it refers to the genies and fetishes that constitute principal aspects of the ancient religions of West Africa and also because it describes a belief in a dual existence for all things - a physical, visible body and a psychic, invisible soul. ${ }^{59}$ According to a young pastor from Macenta who I interviewed, and as confirmed by several other sources of key informants, the population of Macenta initially attributed the origin of the disease (in this region at least) to a curse that was only affecting the Kissi ethnic group because the first 11 deaths solely affected people belonging to this ethnic group. Here is what was stated:

... On arrival with all the rumours we heard in Conakry, I really did not believe in the beginning that it [the Ebola virus disease] must be true because I thought it was an issue of the Kissi (...) Because it had started in Macenta with the Kissi, the first 11 deaths were almost only Kissi. So we thought it was something related to it ... And so we, as Toma, it was not going to touch us, it is like that at the beginning we perceived things (...) Not something genetic, we thought about the fetishism and idolatry activities that people exercised and that can influence them in one way or another ... The first rumour that was there, in Macenta, the first death was the Doctor who was dead in front of everyone's views. People said they have an idol called 'Doma' and so when a person dies of that according to the tradition and according to what is done. And those who are on the thing [those who belong to the secret society of 'Doma'] have no right to touch, to manipulate the corpse, or to see it otherwise they may die (...) And that, it existed before. It is a 
kind of secret society, so they have told us that it can certainly be that, that it is why they [the Kissi] are just dying successively. ${ }^{60}$

According to these discourses, a health worker from Guéckédou hospital (S14), who had gone to seek treatment at his friend's house at Macenta hospital (S15), belonged, like him, to a secret initiation society called 'Doma' which is also the name of a very powerful fetish; so powerful that it can cause a very fast death for its owner if it has been touched by someone else belonging to the same secret society. ${ }^{61}$ When the Guéckédou health worker's body was moved, the doctor from Macenta would have touched this fetish, idol, sacred object, often hidden in the owner's boubou (traditional clothing). By touching the sacred, the fetish got upset causing the brutal death of the director of Macenta's hospital very soon after this event. At that point, in order to repair this transgression and calm the anger of the fetish, six more deaths must succeed each other to reach the symbolic number of seven. If the number of sudden and rapid deaths reaches eight, it means that the fetish is very powerful, and, as a result, seven additional deaths must occur to reach 14 deaths to restore harmony and repair sacrilege. If we reach 15 deaths, we must go to 21 deaths before the disturbed order is restored and moreover that the stain is 'washed', and so on. ${ }^{62}$ Since the first 11 deaths of this second chain were indeed members of this Kissi ethnic group (Fig. 7.3), the 'animist' explanatory model of the disease was quite consistent with people's observations and gained legitimacy among the population at the expense of the biomedical discourse of the existence of EVD. As the susceptibility of dying from Ebola was initially and predominantly perceived as restricted to this particular ethnic group, no preventive measures were adopted by the non-Kissi population of the region. Among the Kissi, the consequent epistemic dissonance between the public health logic and the transgression to be restored led between June and July 2014 twenty-six Kissi-speaking villages in Guéckedou Prefecture to isolate themselves from Ebola response, cutting bridges and felling trees to prevent vehicle access, and stoning intruding vehicles. ${ }^{63}$ Because it is a disease of the social- of those who look after and visit others, and of those who attend funerals - there are of course many reasons why the Ebola phenomenon was likely to be associated with sorcery. It is also not a coincidence that the triggering event, the transgression, in this explanatory model was attributed to medical doctors. As elite Africans generally educated in European ways and relatively wealthy, this social group displays many characteristics of sorcerers (they lead a secluded life, do not share 
their gains, exchange abrupt greetings, eat large quantities of meat and eat alone). ${ }^{64}$ Moreover, the intense preoccupation throughout this region with 'hidden evil in the world around you that finds dramatic expression in the clandestine activities of witches and the conspiracies of enemies' is exacerbated by tiny pathogens remaining largely invisible to our routine social practices, hence attracting suspicions of sorcery (Fig. 7.3) ${ }^{65}$

Following the investigation of this 'animist' model in relation to the strong community resistance manifested in Forest Guinea, I interviewed a member of the Riposte communication unit originating from Macenta about the Dandano case ${ }^{66}$ :

Yes, there is the specificity of Dandano. (...) [In] Dandano there was a great witch doctor who had gone to greet his counterpart witch doctor where there were a lot of cases. And that is where he got infected. He returned to Dandano. Three days later he developed the disease and died. Afterwards, as he is a great, recognised witch doctor, people said to themselves, because he died, it was not Ebola that killed him but his fetish that is taking revenge on him because it is a betrayal to leave one's domain to greet one's friend. Maybe he went to spy on his friend and his friend hit him ... Well, there have been many versions. (...) Among the old people who knew the drug he had, euh... his fetish, the grigri that he had, and that if it was his grigri who killed him, it means that all those who saw him, who saw his body, must also suffer. (...) [we could] see his dead body because he was not protected, because we had to wash him and there were medicines that had to be poured to annihilate his fetishes' power before burying him. So there must have been deaths, hence it was already premeditated. Then there were deaths, as it was said, and they were successive deaths. That means there were deaths, two days, three days, so people put more anathema on what happened. And that is how Dandano lived things. So there were deaths, we said it is the fetish that woke up because Dandano is known as a village of powerful fetishes, that is known. (...) Even all the sensitisation we do, we never stop in Dandano on a manager, a notable, otherwise they can do something to you ... So it is well recognised (...) Dandano, is not where you have to go joking. (...) At the end, with a lot of deaths, a lot of funerals, they saw that no, it is not that [the fetish anger] anymore, and with the information here and there, it is Ebola. And it is like that with all the negotiations (...). ${ }^{67}$

Notably, these explanatory models are distinct from general beliefs about diseases and care techniques in the region. We cannot argue then that 'biomedicine' and 'Kissi culture' are somehow distinct and opposed. ${ }^{68}$ 


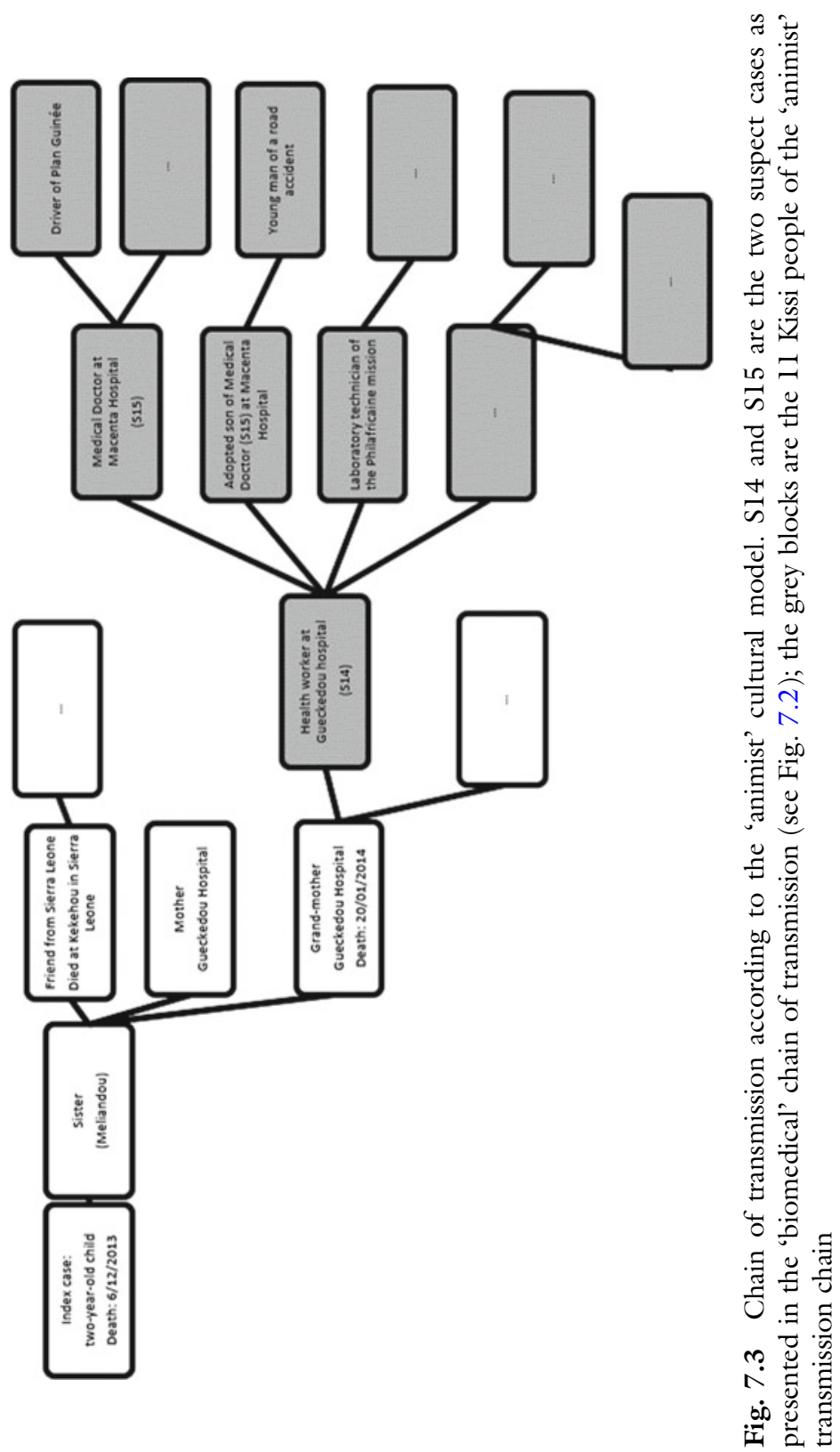


These beliefs belong to the ideology of different sectors of the care system and exist independently of the illness of a subject. Explanatory models are collected in response to a particular episode of illness in a given subject in a given sector and can evolve over time, depending on how the experience, knowledge and risk exposure of the concerned individual develop. This is precisely what has been reported to us and what has been observed in Forest Guinea. As the number of deceased progressed, and according to the religious and/or ethnic affiliation of the deceased, a new explanatory model was put in place as stated in this conversation:

Yes, at first it was said, when I was in Conakry, since our country is predominantly Muslim, it was said that it is a matter for Christians since Muslims do not eat apes. Muslims do not eat the bat. It's only the foresters who eat that. And that's why this disease hits only the Kissi and Toma who are from the forest. So it's a Kaf disease.

- Kaf? (Séverine Thys)

- From unbelievers, Pagans who do not know God. We call Kaf, all those who do not believe in the God of Muslims. ${ }^{69}$

This last extract particularly highlights the fact that these explanatory models are not fixed in time and space and are not impervious to each other either. Indeed, the first health messages communicated to the population and built on the biomedical model were intensely focused on the need to avoid the consumption of 'bushmeat', especially wild animals identified as potential primary sources of contamination, namely monkeys and bats. The content of these messages gave birth to another popular model, in which the food taboos or eating habits observed by members affiliated to a certain religion allowed them to explain why this disease was affecting certain groups and not others. ${ }^{70}$ This quote also perfectly illustrates how popular discourses have integrated medical interpretations or public health messages. In the study conducted by Bonwitt et al. about the local impact of the wild meat ban during the outbreak, all participants, irrespective of age or gender, were aware of wild mammals acting as a source of transmission for Ebola. Yet a confusion remained about which species in particular could transmit the Ebola virus, which may be due to the content of public health messages that were inconsistent as regards the species shown to be potentially hazardous. ${ }^{71}$ Messages are being absorbed, but in such chaos and fear, people process information according to their own 
worldview, according to the sources available to them, and following their personal experiences and instincts. Furthermore, the criminalisation of wild meat consumption, which fuelled fears and rumours within communities, did entrench distrust towards outbreak responders and also exacerbated pre-existing tensions within villages, ethnicities and religions. ${ }^{72}$

Following the Kissi, it seemed that it was the Muslim community that was hit by sudden and numerous deaths. To cope with this new upheaval, this new incomprehension, the operated explanatory model of these deaths' origin was, consequently, first that of a 'maraboutage':

It started like that until a certain moment. And then it turned upside down. There have always been upheavals. It turned upside down, and instead of being weighed at a certain moment on the Toma and the Kissi, it was rather on the Manyas, who are entirely, 99\%, 100\% even Muslims. And so people started saying 'Ha! that only attacks Muslims, why not Christians?'. So there has always been upheaval in all the procedures of this disease evolution. ${ }^{73}$

\section{Whose Knowledge Counts?}

As noted by Hewlett et al., 'Patients, physicists, caregivers and local people in different parts of the world have cultural patterns for different diseases. Providing care and appropriate treatment for a particular disease is often based on negotiation between these different models' ${ }^{74}$ To be able to negotiate, it is necessary that each one, doctor and patient, partakes in the knowledge of the explanatory model of the other.

While most health professionals rarely assume that people have and construct their own interpretation of the causal chain, my ethnographic observations presented in this chapter demonstrate that the a priori on which all interventions of sensitisation are based is not only incorrect, but also a source of blockages for the adoption of prescribed behaviours. This is because, to return to Hewlett et al., 'people do not just follow the continuous thread of learning; they also develop an ability to articulate adherence to prescribed behaviours with the refusal of others, to cooperate at certain times and to show reluctance to others, inviting the analysis to move towards a sociology of compromise'. ${ }^{75}$

Through the example of funerals, Wilkinson and Leach have also cast light on the presumption that the knowledge needed to stop the epidemic is held by public health experts and scientists, and not by local people. ${ }^{76}$ This very often leads to the development of protocols and procedures that 
completely negate the contribution of communities. ${ }^{77}$ This asymmetrical reflection between caregivers and care receivers, the structural violence that has cultivated inequalities in this region, the heterogeneity of experiences seen by the populations as fundamental contradictions between words and facts, the confidence and trust crisis since the 'demystification' programme initiated during Sékou Touré's time, and the traumas inflicted by a transgression of usages in the name of urgency and the exceptional nature of the Ebola epidemic, are all realities that have fueled community reluctance and resistance. ${ }^{78}$ The late involvement of traditional healers, primarily consulted by Guineans when experiencing illness, in the activities of the response in Macenta, is another example of this asymmetry, which too often omits to acknowledge and relate to these other categories that support the social fabric, even if since Alma Ata in 1978 these stakeholders should no longer be on the margins of the health system. ${ }^{79}$

Although the concept of explanatory models is not sufficient to explain all the failures of response in the context of Guinea, or the bordering regions with Sierra Leone and Liberia, nevertheless it allows to move past linear technical discussions of 'weak health systems' as the main reason for the scale of the disaster. The use of this conceptual framework for understanding popular interpretations of the origin of the disease and its transmission reveals the complex, historically rooted and multidimensional picture of the Ebola crisis. Several authors agree that, 'in any case, it is not a question of archaic beliefs or outlier depictions, but good answers - which can be called rational in this context - to a vital emergency situation, interpreted in the light of past and present experiences'. ${ }^{80}$

A better knowledge and comparison of these discourses and different cultural models of the disease, sometimes incorporated, sometimes hermetic, could nevertheless contribute considerably to the success of the fight against the epidemic, especially when it concerns the improvement of knowledge of the chains of disease transmission, the identification and understanding of the behaviours of local populations, and of the sources of denials and rumours. Explanatory models proposed by the biomedical sciences are very often in competition and in contradiction with diagnoses made by traditional healers and especially with rumours involving divine punishments, breaches of prohibitions, the misdeeds of wizards or genies, or virologic warfare. ${ }^{81}$ If this 'animist' model is not identified nor recognised as making sense for others at the key moment, there will also be no negotiation and no understanding of the distances and proximities existing between the thought systems present in the 
concerned ecosystems. An anthropological approach remains essential to adapting this response to local realities. Epelboin further argues that 'local models of causation regarding misfortune, often the most predominant, involve not only the virulence of the virus and human behaviour, but the evil actions of human and non-human individuals. The virologic model is then only one explanatory model among others, leaving the field open to all social, economic and political uses of misfortune' ${ }^{82}$

Following the re-emergence of this infectious disease of zoonotic origin in a whole new social ecosystem, a cross-sectoral research agenda, the so-called One Health integrated approach, has finally emerged in the field of viral haemorrhagic fevers, also enabling the role of anthropology to be expanded to times of epidemic outbreak. Until then, anthropologists were mandated to contribute to the adaptation and improvement of immediate public health interventions in relation to human-to-human transmission. Yet, the growing interest of anthropologists in the interaction between humans and non-humans has made it possible to extend their research topic to the complex dynamics of the primary and secondary transmission of the virus. ${ }^{83}$ In addition, this anthropological interest has provided a new cross-cultural perspective on the movement of pathogens and has therefore improved knowledge about the mechanisms of emergence, propagation and amplification of a disease located at the interface between humans and wildlife. ${ }^{84}$ Such was the role of Almudena Marí Saéz and colleagues who, in a multidisciplinary team, conducted an ethnographic study in the village of the Ebola epidemic's origin, the index case village, to better understand local social hunting practices and the relationships between bats and humans. ${ }^{85}$ However, the realm of the human-animal-disease interaction has been limited to 'natural versus cultural' domains and frequently conceived as a biological phenomenon in One Health studies instead of a biocultural one integrating the social and cultural dimensions generated by human-animal relations. Incorporating anthropology into One Health approaches should provide a more nuanced and expanded account of the fluidity of bodies, categories and boundaries as drawn up by existing ethnographies on cattle in East and Southern Africa for example. ${ }^{86}$

Epelboin et al. have stressed that, 'The anthropological approach in previous epidemics has confirmed that the urgency and severity of an epidemic must not prevent people from listening to them and thinking throughout the epidemic of taking into account indigenous codes, customs, knowledge, skills and beliefs' ${ }^{87}$ By taking seriously the possibility that affected people in the places where we do research or implement control measures 
might not see things in the same way, we have to be willing to have our categories (such as culture/nature, human/animal, mind/body, male/female, caregivers/care receivers) unsettled, and to grapple with the practical implications of this for engagement in field sites, for knowledge-sharing and for the design of interventions, in the hope that such improvements might contribute to a future prevention of Ebola and to public health policies more suitable to respond to people's basic needs. ${ }^{88}$ It also allows the affected people themselves to have a say in the matter. As Philippe Descola and other anthropologists have argued, on the basis of a comparative analysis of a wide range of ethnographic work across the continents, native classificatory systems usually offer a continuum, rather than sharp divisions, among humans and other animal species. ${ }^{89}$ Indeed, human dispositions and behaviours are attributed not only to animals but also to spirits, monsters and artefacts, contrasting to modern Western models, which generally see the categories of human and non-human as clearly defined and mutually exclusive. ${ }^{90}$

The ability to sense and avoid harmful environmental conditions is necessary for the survival of all living organisms and, as Paul Slovic has argued, 'humans have an additional capability that allows them to alter their environment as well as respond to it'. ${ }^{91}$ As regards the emerging violence in conservation as either against nature (e.g. culling bats) or in defence of it (e.g. rearranging landscapes within an inclusive 'One Health' approach), James Fairhead proposes that such violence is increasingly between 'the included' and 'rogues' in ways that transcend the nature/society binary. ${ }^{92}$ While the 'white', and African elites were seen by the affected population as 'antisocial' intruders or rogues, suspected of sorcery and using Ebola as a tool for political manipulation, those involved in the struggle to address the Ebola epidemic were not fighting just against the virus but also against the natural world that harboured it: the rogues which included villainous bats but moreover habitat destroyers, namely hunters, bushmeat traders and deforesters. These were the humans casted as the ones invading the habitat of the virus.

Since EVD will be constantly reconceptualised, and because of new scientific discoveries (e.g. on natural reservoir, or vaccine development), control interventions must listen to and take into account popular perceptions as well as the socio-cultural and political context and their respective evolution. Rumours must be identified and managed on a case-by-case basis without global generalisation that could reinforce misinterpretations on the assumption that ignorance alone generates these rumours, con- 
flicts, lack of trust and resistance. Moreover, zoonotic epidemic fighters should follow MacGregor's and Waldman' recommendations by starting to think differently with and about animals and about species boundaries in order to generate novel ways of addressing zoonotic diseases, allowing for closer integration with people's own cultural norms and understandings of human-animal dynamics. ${ }^{93}$

Acknowledgements I would like to thank Tenin Traoré, a Guinean sociologist and consultant to WHO, and Joseph Kovoïgui, assistant coordinator of the Philafrican Mission and then consultant to WHO, for their commitment and engagement in the fight against Ebola, their generosity, their knowledge, their experience and our fruitful collaboration in many respects. I would also like to thank the coordination team and the DPS (Prefectural Health Direction) of Macenta for their welcome and sincere attention; GOARN/WHO, Antwerp Institute of Tropical Medicine, and in particular Prof. Marleen Boelaert for emotional, financial and logistical support; Dr. Alain Epelboin for field preparation and numerous sharing with the Francophone Anthropological Platform; and Christos Lynteris for his invitation to connect and exchange with the Anglophone 'Anthro-Zoonoses' network and contribute to this timely collection.

\section{Notes}

1. World Health Organisation, 'Ebola Virus Disease in Guinea-Update (Situation as of March 25, 2014)' (accessed May 7, 2019). https://www.who. int/csr/don/2014_03_25_ebola/en/.

2. R. Migliani, S. Keïta, B. Diallo, S. Mesfin, W. Perea, and B. Dahl, 'Aspects épidémiologiques de la maladie à virus Ebola en Guinée (décembre 2013-avril 2016)'. Bulletin de la Société de pathologie exotique (2016): $1-18$.

3. S. Baize, D. Pannetier, L. Oestereich, T. Rieger, L. Koivogui, N. Magassouba, B. Soropogui, M. S. Sow, S. Keïta, H. De Clerck, A. Tiffany, G. Dominguez, M. Loua, A. Traoré, M. Kolié, E. R. Malano, E. Heleze, A. Bocquin, S. Mély, H. Raoul, V. Caro, D. Cadar, M. Gabriel, M. Pahlmann, D. Tappe, J. Schmidt-Chanasit, B. Impouma, A. K. Diallo, P. Formenty, M. Van Herp, and S. Günther, 'Emergence of Zaire Ebola Virus Disease in Guinea'. The New England Journal of Medicine 371:15 (2014): $1418-1425$.

4. For the single zoonotic transmission, see A. M. Saéz, S. Weiss, K. Nowak, V. Lapeyre, F. Zimmermann, A. Düx, H. S. Kühl, M. Kaba, S. Regnaut, K. Merkel, A. Sachse, U. Thiesen, L. Villányi, C. Boesch, P. W. Dabrowski, A. Radonić, A. Nitsche, S. A. J. Leendertz, S. Petterson, S. Becker, V. Kräh- 
ling, E. Couacy-Hymann, C. Akoua-Koffi, N. Weber, L. Schaade, J. Fahr, M. Borchert, J. F. Gogarten, S. Calvignac-Spencer, and F. H. Leendertz, 'Investigating the Zoonotic Origin of the West African Ebola Epidemic'. EMBO Molecular Medicine 7:1 (2014): 17-23.

5. F. Keck and C. Lynteris, 'Zoonosis: Prospects and Challenges for Medical Anthropology'. Medical Anthropology Theory 5:3 (2018): 1-14.

6. P. Wald, Contagious: Cultures, Carriers, and the Outbreak Narrative (Durham, NC: Duke University Press, 2008). In this outbreak story, a disease emerges in a remote location and spreads across a world highly connected by globalisation and air travel to threaten 'us all' - read the globally powerful North: see A. Wilkinson and M. Leach, 'Briefing: Ebola-Myths, Realities, and Structural Violence'. African Affairs 114:454 (2015): 136-148; F. Keck, 'Ebola, Entre Science et Fiction'. Anthropologie et Santé 11 (2015). https://journals.openedition.org/anthropologiesante/1870.

7. D. Ofri, 'Contagious: Cultures, Carriers, and the Outbreak Narrative: Wald Priscilla. Duke University Press, 2008'. Journal of Public Health 31:3 (2009): 457-458.

8. According to R. Kock, the global focus on wildlife as a major contributor to emerging pathogens and infectious diseases in humans and domestic animals is due to reports which are not based on field, experimental or dedicated research but rather on surveys of literature and research regarding human immunodeficiency virus (HIV) and AIDS, severe acute respiratory syndrome (SARS) and highly pathogenic avian influenza (HPAI), all of which have an indirect wildlife link: R. Kock, 'Drivers of Disease Emergence and Spread: Is Wildlife to Blame?'. Onderstepoort Journal of Veterinary Research 81:2 (2014): 1-4.

9. D. M. Pigott, N. Golding, A. Mylne, Z. Huang, A. J. Henry, D. J. Weiss, O. J. Brady, M. U. G. Kraemer, D. L. Smith, C. L. Moyes, S. Bhatt, P. W. Gething, P. W. Horby, I. I. Bogoch, J. S. Brownstein, S. R. Mekaru, A. J. Tatem, K. Khan, and S. I. Hay, 'Mapping the Zoonotic Niche of Ebola Virus Disease in Africa'. Elife 3 (2014): 1-29. On how and why 'bushmeat' hunting leads to the emergence of novel zoonotic pathogens see: M. LeBreton, A. T. Prosser, U. Tamoufe, W. Sateren, E. Mpoudi-Ngole, J. L. D. Diffo, D. S. Burke, and N. D. Wolfe, 'Patterns of Bushmeat Hunting and Perceptions of Disease Risk Among Central African Communities'. Animal Conservation 9:4 (2006): 495-495; N. D. Wolfe, P. Daszak, A. M. Kilpatrick, and D. S. Burke, 'Bushmeat Hunting, Deforestation, and Prediction of Zoonoses Emergence'. Emerging Infectious Diseases 11:12 (2005): 1822-1827; and N. D. Wolfe, C. P. Dunavan, and J. Diamond, 'Origins of Major Human Infectious Diseases'. Nature 447:7142 (2007): 279-283.

10. S. Paige, C. Malave, E. Mbabazi, J. Mayer, and T. L. Goldberg, 'Uncovering Zoonoses Awareness in an Emerging Disease "Hotspot". Social Science 
and Medicine 129 (2015): 78-86; J. Bonwitt, M. Dawson, M. Kandeh, R. Ansumana, F. Sahr, H. Brown, and A. H. Kelly, 'Unintended Consequences of the "Bushmeat Ban" in West Africa during the 2013-2016 Ebola Virus Disease Epidemic'. Social Science and Medicine 200 (2018): 166-173.

11. Keck, 'Ebola, entre science et fiction'; P. M. Rabinowitz, L. Odofin, and F. Joshua Dein, "From "Us vs. Them" to "Shared Risk": Can Animals Help Link Environmental Factors to Human Health?’. EcoHealth 5 (2008): 224-229.

12. World Health Organisation, 'Statement on the lst Meeting of the IHR Emergency Committee on the 2014 Ebola Outbreak in West Africa' (accessed May 7, 2019). https://www.who.int/mediacentre/ news/statements/2014/ebola-20140808/en/.

13. D. M. Pigott et al., 'Mapping the Zoonotic Niche of Ebola Virus Disease in Africa'; A. Kelly and A. Marí-Saéz, 'Shadowlands and Dark Corners: An Anthropology of Light and Zoonosis'. Medicine Anthropology Theory 5:3 (2018): 43-70.

14. For more information about 'geographies of blame', see P. Farmer, AIDS and Accusation: Haiti and the Geography of Blame (Berkeley, CA: University of California Press, 1992). Regarding the term 'hotspot', Sarah B. Paige and colleagues (2015) explain that it originally referred to a location with high biodiversity and wildlife density that was under significant threat of degradation or destruction as a consequence of human activities; see N. Myers, R. A. Mittermeier, C. G. Mittermeier, G. A. B. da Fonseca, and J. Kent, 'Biodiversity Hotspots for Conservation Priorities'. Nature 403:6772 (2000): 853-858. This became an analytic in emerging infectious disease literature following the work of Kate E. Jones et al. (2008) who demonstrated the spatial overlap between locations of emerging zoonotic diseases and biodiversity hotspots; K. E. Jones, N. G. Patel, M. A. Levy, A. Storeygard, D. Balk, J. L. Gittleman, and P. Daszak, 'Global Trends in Emerging Infectious Diseases'. Nature 451:7181 (2008): 990-993. This visioning practice has extended the idea of a 'hotspot' from a tool for targeting conservation resources to a practice of predicting the source of the next global pandemic. From an ethnographic interest in the social production of space, Hannah Brown and Anne Kelly (2014) used the concept of hotspot to capture the complex relationality of viral haemorrhagic fevers and enrich conceptualizations of viral movement by elaborating the circumstances through which viruses, humans, objects and animals come into contact; H. Brown and A. H. Kelly, 'Material Proximities and Hotspots: Toward an Anthropology of Viral Hemorrhagic Fevers'. Medical Anthropology Quarterly 28:2 (2014): 280-303. See also Keck and Lynteris 'Zoonosis: Prospects and Challenges for Medical Anthropology'. For the mapping 
attempt of the zoonotic niche of EVD, see David M. Pigott et al., 'Mapping the Zoonotic Niche of Ebola Virus Disease in Africa'.

15. Wald, Contagious: Cultures, Carriers, and the Outbreak Narrative; K. A. Mason, 'Becoming Modern After SARS: Battling the HINl Pandemic and the Politics of Backwardness in China's Pearl River Delta'. Bebemoth 3:3 (2010): 8-35. The term 'exceptionality' is borrowed from S. L. Faye, 'L' “exceptionnalité" d'Ebola et les "réticences” populaires en Guinée-Conakry. Réflexions à partir d'une approche d'anthropologie symétrique'. Anthropologie et Santé 11 (2015). https://journals. openedition.org/anthropologiesante/1796.

16. S. Abramowitz, 'Epidemics (Especially Ebola)'. Annual Review of Anthropology 46:1 (2017): 421-445.

17. K. Sams et al., 'From Ebola to Plague and Beyond: How Can Anthroplogists Best Engage Past Experience to Prepare for New Epidemics?' Cultural Anthropology (Fieldsights) (December 2017). https://culanth.org/ fieldsights /from-ebola-to-plague-and-beyond-how-can-anthropologistsbest-engage-past-experience-to-prepare-for-new-epidemics. For the policy relevance of anthropological expertise and a (self-)critical reflection on Ebola and on anthropological (and more broadly social scientific) engagements with humanitarian response, see A. Menzel and A. Schroven, 'The Morning After: Anthropology and the Ebola Hangover'. Integration and Conflict Along the Upper Guinea Coast/West Africa (IC_UGC) (February 17, 2016) (accessed May 7, 2019). https://upperguineacoast. wordpress.com/2016/02/17/the-morning-after-anthropology-and-theebola-hangover-by-anne-menzel-and-anita-schroven-2016/; C. Bolten and S. Shepler, 'Producing Ebola: Creating Knowledge In and About an Epidemic'. Anthropological Quarterly 90:2 (2017): 349-368.

18. Faye, 'L' “exceptionnalité" d'Ebola et les "réticences" populaires en Guinée-Conakry'. The term 'Riposte' is the French name used to designate the official national mobilisation settled to respond to the EVD crisis, structured into two poles, an inter-ministerial committee and a national coordination committee grouping together the international actors and the national non-governmental organisations; see M. Fribault, 'Ebola en Guinée: violences historiques et régimes de doute'. Anthropologie et Santé 11 (2015). https://journals.openedition.org/anthropologiesante/1761. The underreporting is due to biases met while following contact persons, a memory bias ( 21 days of follow up) and a bias of prevarication because of the strong stigmatisation regarding the Ebola Virus Disease (EVD), and the popular resistance to the control methods; see Migliani et al., 'Aspects épidémiologiques de la maladie à virus Ebola en Guinée (décembre 2013-avril 2016)'. 
19. Ibid.; T. Garske, A. Cori, A. Ariyarajah, I. M. Blake, I. Dorigatti, T. Eckmanns, C. Fraser, W. Hinsley, T. Jombart, H. L. Mills, G. Nedjati-Gilani, E. Newton, P. Nouvellet, D. Perkins, S. Riley, D. Schumacher, A. Shah, M. D. Van Kerkhove, C. Dye, N. M. Ferguson, and C. A. Donnelly 'Heterogeneities in the Case Fatality Ratio in the West African Ebola Outbreak 2013-2016'. Philosophical Transactions of the Royal Society B: Biological Sciences 372:1721 (2017): 20160308. https://doi.org/10.1098/rstb.2016. 0308 .

20. For what poor coordination mechanisms posed problem in Guinea, see S. Thiam, A. Delamou, S. Camara, J. Carter, E. K. Lama, B. Ndiaye, J. Nyagero, J. Nduba, and M. Ngom, 'Challenges in Controlling the Ebola Outbreak in Two Prefectures in Guinea: Why did Communities Continue to Resist?' The Pan African Medical Journal 22:Suppl 1 (2015): 1-5.

21. A. Wilkinson and J. Fairhead, 'Comparison of Social Resistance to Ebola Response in Sierra Leone and Guinea Suggests Explanations Lie in Political Configurations Not Culture'. Critical Public Health 27:1 (2017): 14-27. For the structural drivers of vulnerability, see also V. Dzingirai, S. Bukachi, M. Leach, L. Mangwanya, I. Scoones, and A. Wilkinson, 'Structural Drivers of Vulnerability to Zoonotic Disease in Africa'. Philosophical Transactions of the Royal Society B: Biological Sciences 372:1725 (2017): 1-9.

22. On the explanation of four social accommodations disrupted by the disease and the humanitarian responses, see J. Fairhead, 'Understanding Social Resistance to the Ebola Response in the Forest Region of the Republic of Guinea: An Anthropological Perspective'. African Studies Review 59:3 (2016): 7-31.

23. Ofri, 'Contagious: Cultures, Carriers, and the Outbreak Narrative'.

24. Keck and Lynteris, 'Zoonosis: Prospects and Challenges for Medical Anthropology'.

25. N. Antoine-Moussiaux, L. J. de Bisthoven, S. Leyens, T. Assmuth, H. Keune, Z. Jakob, J. Hugé, and M. P. M. Vanhove, 'The Good, the Bad and the Ugly: Framing Debates on Nature in a One Health Community'. Sustainability Science (2019): 1-10; Fairhead, 'Understanding Social Resistance to the Ebola Response in the Forest Region of the Republic of Guinea: An Anthropological Perspective'.

26. Ibid. On the division and categories of nature-culture, see M. El-Kamel Bakari, 'Sustainability and Contemporary Man-Nature Divide: Aspects of Conflict and Alienation'. Consilience: The Journal of Sustainable Development 13:1 (2014): 195-216; M. Mullin, 'Animals and Anthropology'. Society and Animals 10:4 (2002): 387-393. On the visual ethnographic examination of the Ebola zoonotic cycle transformed into tools of public health communication by the US CDC during the outbreak of 2014-2016, see C. Lynteris, 'Zoonotic Diagrams: Mastering and Unsettling Human-Animal 
Relations'. Journal of the Royal Anthropological Institute 23:3 (2017): $463-485$.

27. Fairhead, 'Understanding Social Resistance to the Ebola Response in the Forest Region of the Republic of Guinea: An Anthropological Perspective'; Keck and Lynteris, 'Zoonosis: Prospects and Challenges for Medical Anthropology'.

28. WHO and its technical partners in the Global Outbreak Alert and Response Network (GOARN) provide technical expertise and support to ministries of health to stop the transmission of the virus in institutions and communities.

29. Migliani et al., 'Aspects épidémiologiques de la maladie à virus Ebola en Guinée (décembre 2013-avril 2016)'.

30. On the Contribution of anthropology to respond to an expectation of translation and cultural mediation on the part of physicians, anxious to convince people of the validity of their biosafety protocols and standards, in the name of the health emergency, see Faye, L' “exceptionnalité” d'Ebola et les "réticences” populaires en Guinée-Conakry'. A common critique made by social scientists working in the context of global health delivery and policy, such as 'One Health', is that their role (if any) is often being relegated to easing delivery and dissemination of pre-established knowledge, reproducing a rather top-down version of scientific expertise; see $S$. Craddock and $S$. Hinchliffe, 'One World, One Health? Social Science Engagements with the One Health Agenda'. Social Science and Medicine 129 (2015): 1-4.

31. Support, social mobilisation and community engagement, contact followup and epidemiological surveillance, logistics, administration.

32. Since 1980 in Guinea, the Mission Philafricaine (MPA), a partner of the Protestant Evangelical Church of Guinea (EPEG) is committed to improving the health of the population in the Macenta prefecture (Forest Guinea) and was therefore mobilised in the fight against EVD.

33. A. Kleinman, Patients and Healers in the Context of Culture. An Exploration of the Borderland Between Anthropology, Medicine and Psychiatry (Berkeley, CA: University of California Press, 1980).

34. B. S. Hewlett, A. Epelboin, B. L. Hewlett, and P. Fortmenty, 'Medical Anthropology and Ebola in Congo: Cultural Models and Humanistic Care'. Bulletin de la Société de Pathologie Exotique 98 (2005): 230-236.

35. Ibid.

36. The aetiology (how individuals refer to the disease?), the timing and mode of onset of symptoms (how do they explain this disease, its cause?), the pathophysiology (which disorder or disfunction they feel occurring in their body?), the evolution of the disorder (including the degree of severity, the type of evolution-acute, chronic...) and the treatment (which treatment is perceived as the most appropriate?), see Kleinman, Patients and Healers in the Context of Culture. 
37. Hewlett et al., 'Medical Anthropology and Ebola in Congo', 231.

38. Bonwitt et al., 'Unintended Consequences of the "Bushmeat Ban" in West Africa during the 2013-2016 Ebola Virus Disease Epidemic'.

39. Baize et al., 'Emergence of Zaire Ebola Virus Disease in Guinea'.

40. Ibid.

41. S. Calvignac-Spencer, H. M. De Nys, M. Peeters, and F. H. Leendertz, 'Maladie à virus Ebola: une zoonose orpheline?'. Bulletin de l'Académie vétérinaire de France 168 (2015): 233-238; Saéz et al., 'Investigating the Zoonotic Origin of the West African Ebola Epidemic'; James Fairhead, 'Technology, Inclusivity and the Rogue Bats and the War Against "the Invisible Enemy"'. Conservation and Society 16:2 (2018): 170-180.

42. About the natural reservoir for Ebola virus see K. J. Olival and D. T. Hayman, 'Filoviruses in Bats: Current Knowledge and Future Directions'. Viruses 6:4 (2014): 1759-1788; E. C. Holmes, G. Dudas, A. Rambaut, and K. G. Andersen, 'The Evolution of Ebola Virus: Insights from the 2013-2016 Epidemic'. Nature 538:7624 (2016): 193-200; E. M. Leroy, B. Kumulungui, X. Pourrut, P. Rouquet, A. Hassanin, P. Yaba, A. Délicat, J. T. Paweska, J.-P. Gonzalez, and R. Swanepoel, 'Fruit Bats as Reservoirs of Ebola Virus'. Nature 438:7068 (2005): 575-576. About the role of the food system in EVD outbreak and spread, see E. M. S. Streng, J. Bergeron, and A. Kircher, 'A Review of the Role of Food and the Food System in the Transmission and Spread of Ebolavirus'. PLoS Neglected Tropical Diseases 9:12 (2015): 1-11.

43. J. Olivero, J. E. Fa, R. Real, M. Á. Farfán, A. L. Márquez, J. M. Vargas, J. P. Gonzalez, A. A. Cunningham, and R. Nasi, 'Mammalian Biogeography and the Ebola Virus in Africa'. Mammal Review 47 (2017): 24-37.

44. On public health messages appearing in West Africa during the height of the outbreak, see K. Post, 'Sending the Right Message: Wild Game and the West Africa Ebola Outbreak'. Health Security 16:1 (2018): 48-57. For information on the 'bushmeat ban', see Bonwitt et al., 'Unintended Consequences of the "Bushmeat Ban" in West Africa during the 2013-2016 Ebola Virus Disease Epidemic'.

45. Food and Agriculture Organization of the United Nations, 'Addressing Zaire Ebola Virus (EBV) Outbreaks. Rapid Qualitative Exposure and Release Assessment'. FAO UN (2015) http://www.fao.org/3/a-i4364e. pdf. On the importance of human-human transmission, see Baize et al., 'Emergence of Zaire Ebola Virus Disease in Guinea'; World Health Organization, 'One Year into the Ebola Epidemic: A Deadly, Tenacious and Unforgiving Virus’. WHO (January 2015) (accessed May 7, 2019). https:// www.who.int/csr/disease/ebola/one-year-report/introduction/en/; R. A. Fowler, T. Fletcher, W. A. Fischer, F. Lamontagne, S. Jacob, D. Brett-Major, J. V. Lawler, F. A. Jacquerioz, C. Houlihan, T. O’Dempsey, M. Ferri, T. Adachi, M.-C. Lamah, E. I. Bah, T. Mayet, J. Schieffelin, 
S. L. McLellan, M. Senga, Y. Kato, C. Clement, S. Mardel, R. C. V. B. De Villar, N. Shindo, and D. Bausch, 'Caring for Critically Ill Patients with Ebola Virus Disease. Perspectives from West Africa'. American Journal of Respiratory and Critical Care Medicine 190:7 (2014): 733-737; Médecins sans Frontières, 'Ebola: Pushed to the Limit and Beyond'. Médecinssans Frontières (March 23, 2015) (accessed May 7, 2019). http:// www.msf.org/en/article/ebola-pushed-limit-and-beyond; Wilkinson and Leach, 'Ebola-Myths, Realities, and Structural Violence'; and Olival and Hayman, 'Filoviruses in Bats: Current Knowledge and Future Directions'.

46. E. Bowen-Jones and S. Pendry, 'The Threat to Primates and Other Mammals from the Bushmeat Trade in Africa, and How this Threat Could Be Diminished'. Oryx 33:3 (1999): 233-246.

47. Wolfe et al., 'Origins of Major Human Infectious Diseases'; Centers for Disease Control and Prevention. 'Facts about Bushmeat and Ebola'. CDC (September 2014) (accessed May 7, 2019). https://stacks.cdc.gov/view/ cdc/25538; M. P. Muehlenbein, 'Disease and Human/Animal Interactions'. Annual Review of Anthropology 45:1 (2016): 395-416.

48. M. McGovern, 'Bushmeat and the Politics of Disgust'. Cultural Anthropology (Fieldsights) (October 2014). https://culanth.org/fieldsights/ 588-bushmeat-and-the-politics-of-disgust; Médecins sans Frontières, 'Ebola: Pushed to the Limit and Beyond'; and A. Benton, "It Don't Take a Semiotician..." Or, What We Talk About When We Talk About Bush Meat'. Mats Utas (August 27, 2014). https://matsutas.wordpress. com/2014/08/27/it-dont-take-a-semiotician-or-what-we-talk-aboutwhen-we-talk-about-bush-meat-by-adia-benton/. The Kellogg Institute, 'Paul Farmer: Taking Up the Challenge of Poverty: Why Accompaniment Matters'. YouTube (April 27, 2016) (accessed May 7, 2019). https:// www.youtube.com/watch? v=JwWT2WylbP8.

49. McGovern, 'Bushmeat and the Politics of Disgust'. On the feeling of disgust as a sentiment with powerful political valences, see also J. Livingston, 'Disgust, Bodily Aesthetics and the Ethic of Being Human in Botswana'. Africa 78:2 (2008): 288-307; W. I. Miller, The Anatomy of Disgust (Cambridge, MA: Harvard University Press, 1997).

50. World Organisation for Animal Health, 'Report of the Meeting of the OIE Working Group on Wildlife (83 SG/13/GT), Taipei, Chinese Taipei, 2014'. World Organisation for Animal Health. (November 2014). http://www.oie.int/fileadmin/Home/eng/Internationa_Standard_ Setting/docs/pdf/WGWildlife/A_WGW_Nov2014.pdf.

51. W. B. Karesh and E. Noble, 2009. 'The Bushmeat Trade: Increased Opportunities for Transmission of Zoonotic Disease'. Mount Sinai Journal of Medicine 76 (2009): 429-434.

52. 'Bushmeat crisis' is caused by the dual threats of wildlife extinctions and declining food and livelihood security of some of the poorest people on 
Earth and whether the hunting of bushmeat is primarily an issue of biodiversity conservation or human livelihood, or both, varies according to perspective, place and over time; see E. L. Bennett, E. Blencowe, K. Brandon, D. Brown, R. W. Burn, G. Cowlishaw, G. Davies, H. Dublin, J. E. Fa, E. J. Milner-Gulland, J. G. Robinson, J. M. Rowcliffe, F. M. Underwood, and D. S. Wilkie, 'Hunting for Consensus: Reconciling Bushmeat Harvest, Conservation, and Development Policy in West and Central Africa'. Conservation Biology 21:3 (2007): 884-887.

53. Bonwitt et al., 'Unintended Consequences of the "Bushmeat Ban" in West Africa during the 2013-2016 Ebola Virus Disease Epidemic'; A. Alpha and M. Figuié, 'Impact of the Ebola Virus Disease Outbreak on Market Chains and Trade of Agricultural Products in West Africa'. Food and Agriculture Organization of the United Nations (2016). http://www.fao.org/ emergencies/resources/documents/resources-detail/en/c/417072/.

54. Post, 'Sending the Right Message: Wild Game and the West Africa Ebola Outbreak'.

55. Bonwitt et al., "Unintended Consequences of the "Bushmeat Ban" in West Africa during the 2013-2016 Ebola Virus Disease Epidemic'; P. Richards, Ebola: How a People's Science Helped End an Epidemic (London: Zed Books, 2016); B. Seytre, 'Les errances de la communication sur la maladie à virus Ebola'. Bulletin de la Société de Pathologie Exotique 109:4 (2016): 314-323.

56. G. M. Sodikoff, 'Zoonotic Semiotics: Plague Narratives and Vanishing Signs in Madagascar'. Medical Anthropology Quarterly 33:1 (2019): 42-59.

57. Fairhead, 'Understanding Social Resistance to the Ebola Response in the Forest Region of the Republic of Guinea: An Anthropological Perspective'.

58. Z. Camara and J. Lazuta, 'One Year On: Why Ebola Is Not Yet Over in Guinea'. IRIN (March 23, 2015). www.irinnews.org.

59. C. R. Ember and M. Ember, Encyclopedia of Medical Anthropology: Health and Illness in the World's Cultures (New York: Kluwer Academic/Plenum, 2004).

60. Extracts of the individual interview conducted with the Pastor, November 10, 2014, Macenta, Guinea-Conakry.

61. On the cultural and political role of initiation societies in the forest region and the related experiences of local citizens in relation to both the Manding (often Islamic) world to the north, and to the 'white' (often Christian) colonial and neo-colonial order, see Fairhead, 'Understanding Social Resistance to the Ebola Response in the Forest Region of the Republic of Guinea: An Anthropological Perspective'.

62. M. Douglas, Purity and Danger, an Analysis of Concepts of Pollution and Taboo (New York: Frederick A. Praeger, 1966).

63. J. Anoko, 'Communication with Rebellious Communities during an Outbreak of Ebola Virus Disease in Guinea: An Anthropological Approach'. 
Ebola Response Anthropology Platform (2014) (accessed May 7, 2019). http://www.ebola-anthropology.net.

64. Fairhead, 'Understanding Social Resistance to the Ebola Response in the Forest Region of the Republic of Guinea: An Anthropological Perspective'; R. Shaw, Memories of the Slave Trade: Ritual and Historical Imagination in Sierra Leone (Chicago, IL: The University of Chicago Press, 2002).

65. Quote from: M. Jackson, Lifeworlds: Essays in Existential Anthropology (Chicago, IL: The University of Chicago Press, 2013), p. 145.

66. For more information about Dandano village 'surrendering their sick and dead after being battered by the virus', see A. Nossiter, 'Fear of Ebola Opens Wary Villages to Outsiders in Guinea'. New York Times (November 16, 2014). https://www.nytimes.com/2014/11/17/ world/africa/fear-of-ebola-opens-wary-villages-to-outsiders-in-guinea. html? searchResultPosition $=1$.

67. Extracts of the individual interview conducted with a voluntary of the communication unit of Macenta, November 14, 2014, Macenta, GuineaConakry.

68. M. Leach, J. R. Fairhead, D. Millimounoc, and A. A. Diallod, 'New Therapeutic Landscapes in Africa: Parental Categories and Practices in Seeking Infant Health in Republic of Guinea'. Social Science and Medicine 66:10 (2008): 2157-2167.

69. Extracts of the individual interview conducted with the Pastor, November 10, 2014, Macenta, Guinea-Conakry.

70. For similar narrative about Muslim communities and food taboos regarding bats, see F. Batty, 'Reinventing "Others" in a Time of Ebola'. Cultural Anthropology (Fieldsights) (October 2014). http://www.culanth. org/fieldsights/589-reinventing-others-in-a-time-of-ebola.

71. Bonwitt et al., "Unintended consequences of the "Bushmeat Ban" in West Africa during the 2013-2016 Ebola Virus Disease Epidemic'.

72. Ibid.

73. Extracts of the individual interview conducted with the Pastor, November 10, 2014, Macenta, Guinea-Conakry.

74. Hewlett et al., 'Medical Anthropology and Ebola in Congo: Cultural Models and Humanistic Care'.

75. Fribault, 'Ebola en Guinée: violences historiques et régimes de doute', my translation.

76. Wilkinson and Leach, 'Briefing: Ebola-Myths, Realities, and Structural Violence'.

77. Ibid.

78. Faye, 'L' “exceptionnalité” d'Ebola et les "réticences” populaires en Guinée-Conakry; Fribault, 'Ebola en Guinée: violences historiques et régimes de doute'; Wilkinson and Leach, 'Briefing: Ebola-Myths, Realities, and Structural Violence'; Bonwitt et al., 'Unintended consequences of the 
"Bushmeat Ban" in West Africa during the 2013-2016 Ebola Virus Disease Epidemic'; F. L. Marcis, “Traiter les corps comme des fagots' Production sociale de l'indifférence en contexte Ebola (Guinée)'. Anthropologie et Santé 11 (2015). https://journals.openedition.org/anthropologiesante/1907.

79. A.-M. Moulin, 'L'anthropologie au défi de l'Ebola'. Anthropologie et Santé 11 (2015). https://journals.openedition.org/anthropologiesante/1954.

80. Ibid., my translation.

81. A. Epelboin, 'Approche anthropologique de l'épidémie de FHV Ebola 2014 en Guinée Conakry'. WHO (2014): 34. https://hal.archivesouvertes.fr/hal-01090291.

82. Ibid., my translation.

83. Keck and Lynteris, 'Zoonosis: Prospects and Challenges for Medical Anthropology'.

84. H. Brown, A. H. Kelly, A. M. Sáez, E. Fichet-Calvet, R. Ansumana, J. Bonwitt, N. Magassouba, F. Sahr, and M. Borchert, 'Extending the "Social": Anthropological Contributions to the Study of Viral Haemorrhagic Fevers'. PLoS Neglected Tropical Diseases 9:4 (2015): 1-4.

85. Saéz et al., 'Investigating the Zoonotic Origin of the West African Ebola epidemic'.

86. H. MacGregor and L. Waldman, 'Views from Many Worlds: Unsettling Categories in Interdisciplinary Research on Endemic Zoonotic Diseases'. Philosophical Transactions of the Royal Society B: Biological Sciences 372 (2017): 1-9; J. G. Galaty, 'Animal Spirits and Mimetic Affinities: The Semiotics of Intimacy in African Human/Animal Identities'. Critique of Anthropology 34:1 (2014): 30-47.

87. A. Epelboin, A. Odugleh-Kolev, and P. Formenty, 'Annexe 13. Contribution de l'anthropologie médicale à la lutte contre les épidémies de fièvres hémorragiques à virus Ebola et Marburg'. In World Health Organisation, Épidémies de fièrres hémorragiques à virus Ebola et Marburg: préparation, alerte, lutte et évaluation, pp. 55-60 (WHO/HSE/GAR/BDP, 2014). https://apps.who.int/iris/bitstream/ handle/10665/130161/WHO_HSE_PED_CED_2014.05_fre.pdf; jsessionid=A2071FCF391EE8D3DECD8BCA0D3A3E09? sequence $=1$.

88. MacGregor and Waldman, 'Views from Many Worlds'; Menzel and Schroven, 'The Morning After: Anthropology and the Ebola Hangover'.

89. P. Descola, Beyond Nature and Culture (Chicago, IL: The University of Chicago Press, 2015); S. Hinchliffe, J. Allen, S. Lavau, N. Bingham, and S. Carter, 'Biosecurity and the Topologies of Infected Life: From Borderlines to Borderlands'. Transactions of the Institute of British Geographers 38:4 (2012): 531-543.

90. A. L. Peterson, 'Nature and Society: Anthropological Perspectives by Philippe Descola and Gisli Palsson, eds.'. Agriculture and Human Values 15:2 (June 1998): 179-183. 
91. P. Slovic, 'Perception of Risk'. Science 236:17 (April 1987): 280-285.

92. Fairhead, 'Technology, Inclusivity and the Rogue Bats and the War Against "the Invisible enemy".

93. MacGregor and Waldman, 'Views from Many Worlds'. 